\title{
Admiral Louis Guillouet, Comte d'Orvilliers (1710-92): A Style of Command in the Age of the American War
}

\author{
Olivier Chaline
}

Université de Sorbonne, Paris

In 2003 Professor Nicholas Rodger noted that: 'British flag officers' styles of command might be located on a scale ranging from the most autocratic and centralized to the most confiding and delegating. Roughly corresponding to this was another scale, of training: those who put most effort into practising fleet manoeuvres seem very often to have been those who were most willing to allow captains to use their judgement in action. ${ }^{163}$ The same could be said about French admirals of that time. On one side were the cases of the Comte de Grasse (1723-88) or the Bailli de Suffren (1729-88), who were hated by many of their officers, and on the other side there was Louis Guillouet, Comte d'Orvilliers (1710-92), whose departure from Brest in September 1779 offered the Grand Corps a unique opportunity to display their love and admiration for him.

Like Jellicoe after him, d'Orvilliers can be described as a man who could have lost a war in one afternoon had he not stood fast against Admiral Keppel at

How to cite this book chapter:

Chaline, O. 2017. Admiral Louis Guillouet, Comte d'Orvilliers (1710-92): A Style of Command in the Age of the American War. In: Harding, R and Guimerá, A (eds.). Naval Leadership in the Atlantic World. Pp. 73-84. London: University of Westminster Press. DOI: https://doi.org/10.16997/book2.g. License: CC-BY-NC-ND 4.0 
the Battle of Ushant on 27 July 1778. However, this is often neglected - even in France. Rather, it is his failure, in the following year, at the head of the French-Spanish fleet in the Western Approaches, that attracts attention. ${ }^{164}$ The historiography, especially in France, has focused on the question of whether the plan for a landing on the south coast of Britain could really have succeeded. D'Orvilliers himself, who resigned soon after his return to Brest, has hardly been considered as an officer in the existing historiography. ${ }^{165}$ This is a pity because he displayed a genuinely personal leadership style, a very different one indeed from that of his fellow French flag officers. His personal and familial archives have been lost, so to understand his leadership style one needs to turn to his correspondence with the Secrétaire d'État de la Marine, at the Archives Nationales in Paris. Three main issues can be probed on the basis of his letters: his teaching skills, his concern about his fleet's cohesion and efficiency and, last but not least, his dignity in command, even when he felt powerless against ministers, the unpredictable natural elements and an epidemic which led him to mourning and failure.

\section{I - Teaching skills}

D'Orvilliers stands out as an admiral blessed with exceptional teaching skills. He spent a long time in charge of the instruction of the Gardes de la Marine, whose three companies at Brest, Rochefort and Toulon were at the beginning of their naval careers in the Grand Corps, the French officer corps. He had to command successively a brigade, a detachment and the whole company, while he himself was promoted from junior officer to capitaine de vaisseau. The bulk of his career took place at Rochefort. The Western maritime province of Saintonge happened to be the birthplace of his wife, Marie de Chesnel d'Escoyeux, daughter of a chef d'escadre. Although d'Orvilliers was born in Moulins, miles away from the coast, he was the son of a governor of French Guyana who had fought at Vélez-Málaga. ${ }^{66} \mathrm{He}$ was a typical enfant du Corps, entering the Gardes de la Marine in 1728, where he received the type of instruction he was later to provide to the younger Gardes members, who like himself, were of the provincial nobility, with a corporate spirit based on family ties rather than wealth.

These were dull times to enter the navy - no wars; no fast-track promotions. D'Orvilliers devoted his entire life to the Grand Corps. True, he took part in the Battle of Toulon, in 1744, but his main activity was the training of generations of young officers for the wars to come. It should be noted that Hubert de Conflans (1690-1777) did the same at Brest just before the beginning of the War of the Austrian Succession. Like Admiral La Galissonnière (1693-1756), commandant de la marine at Rochefort, d'Orvilliers came to the early conclusion that the best way of making good naval officers was to train them on sea rather than on land. 
An important chance encounter was his meeting with the future vice-admiral, Jean-Baptiste Macnémara (1690-1756), like La Galissonnière, one of the most promising French flag officers at that time. From 1739, d'Orvilliers sailed many times under Macnémara's command and was selected, in 1750 and 1754, for two of the first escadres d'évolutions. These were organised for naval training, not for young officers but for selected captains. In 1754, as he was 44 years old, he was promoted to the rank of capitaine de vaisseau and was highly rated as an 'excellent officer despite his little fortune'. His career now seems to have assumed a rather speedy course. On the eve and at the beginning of the Seven Years' War (1756-63), d'Orvilliers was trained by good tacticians like Macnémara, Hilarion-Josselin Duguay (1692-1760) and Dubois de La Motte (1683-1764), especially in squadrons intended to reinforce and resupply French Canada. On these voyages, manoeuvres were more important than fighting. French Admirals sailing for Quebec or Louisbourg were instructed to achieve something other than the defeat of the enemy. The main objective for a navy in an inferior position was to keep sea routes open without being destroyed. However, after 1757, wear and tear, disease (d'Orvilliers was lucky enough to escape typhus in Dubois de La Motte's squadron returning from Louisbourg) and the British blockade made that objective unattainable.

D'Orvilliers didn't take part in the crushing defeats of 1759 . His reputation remained thus unstained. When the time came to rebuild the navy he was one of the up-and-coming men on which a minister could rely. On 1 October 1764 he was promoted to chef descadre, the first rank of flag officer. In 1772, he was chosen to command the first escadre d'évolutions, or training squadron, organized since the Peace of Paris in 1763. ${ }^{167}$ What he had achieved with junior officers of the Gardes de la Marine, he now had to achieve with more senior and experienced captains, and even with two other flag officers. The chef descadre, the Comte du Chaffault (1708-94), was two years older than him and offended that he had to obey a younger officer. The purpose of this training squadron of three warships, six frigates and three corvettes was to get officers and crews to practise a lot of manoeuvres together, obeying the orders and signals given to them. At this point, we should note that the Chevalier du Pavillon was present on board the new Alexandre (64), d'Orvilliers' flagship. For little more than three months, the squadron was trained by d'Orvilliers cruising from Brest to the Cape Saint-Vincent. He supervised a considerable number of naval exercises involving his flag officers and captains: for example, how to stand in a bow and quarter line, to chase, to tack in succession, and so on. They were required to practise again and again until they got things right. D'Orvilliers, as a clear-headed and patient training officer, only worked with a small number of rather straightforward manoeuvres, but the more practised his captains were, the better trained officers they became.

For d'Orvilliers there was another purpose to the training squadron: to single out deserving men for the next war against Britain. The admiral wrote a series of apostils; that is, teacher's assessments of the captains and junior officers who 
sailed under his command. ${ }^{168}$ Some did not deserve promotion. Others seemed to be beginning a promising career, like his own nephew Hugon de Givry, who 'combines willpower and talents and promises to turn into a great officer'. Moreover, there were some officers who enjoyed a fast-track promotion, like the Chevalier du Pavillon:

'an officer who stands out as much for his wide-ranging command of the theory as his zeal and enthusiasm. With his remarkable eye for details, he belongs to the few who deserve, on the basis of a trial-and-error method, to be entrusted with a commanding position, rather than be relegated to some ancillary task'.

Given their strong personalities, three of d'Orvilliers's assistants clearly deserved praise and recognition. First was Du Chaffault. D'Orvilliers sought to treat him courteously in order to placate Du Chaffault's resentment against him. These were his simple words: 'Well above my approval; I hope to have deserved his.' About the Comte de Grasse, he wrote:

'He is the captain who manoeuvred the best and although his frigate was of very low quality, he nevertheless made the best out of his manoeuvres, the most precise and brilliant possible. His frequent collisions during that campaign show room for improvement (...) but in fact the comte de Grasse is a highly distinguished captain who is fit to command the King's squadrons and naval armies.'

The third officer was the Comte de la Motte-Picquet (1720-91), 'the only one who can fight with M. De Grasse for the best way to keep his station and to manoeuvre precisely. He took all the advantage possible from a very bad ship. Flag officers would be perfectly guilty not to undertake the greatest enterprises with captains of such merit.'

That training squadron was for d'Orvilliers an exceptional moment, when he had under his command Du Chaffault, Latouche-Tréville, de Grasse, la Motte-Picquet and La Clochetterie. Six years later, the last in this list was the commander of the frigate La Belle Poule (26), which successfully fought off the British Arethusa (32) on 17 June 1778 and precipitated the outbreak of war between France and Britain.

In 1773, the King and his minister were satisfied with the training cruise. The same cannot be said of d'Orvilliers. Committed as he was to his Corps, he knew how badly reforms were needed to fend off criticism (especially regarding the training of officers). Nevertheless, at the beginning of Louis XVI's reign, on 1 March 1775, he was chosen by the King and the minister of the navy, AntoineRaymond-Gualbert-Gabriel de Sartine (1729-1801), to command the navy at Brest. Thus, he assumed the leadership of France's main arsenal and of the fleet mounting guard in front of Britain. 


\section{II - D'Orvilliers's concern for his fleet's cohesion and efficiency}

When he was promoted to the rank of lieutenant général des armées navales in 1777, and the following year when he was given command of the great fleet concentrated at Brest, D'Orvilliers had reached the climax of his naval career. From that time on, he was addressed as Comte (Earl) in his official correspondence. He took on board his flagship his own son, the lieutenant de vaisseau Louis Claude d'Orvilliers de Château-Chesnel, and two nephews, the enseignes de vaisseau Louis Gilbert d'Orvilliers and Claude Hugon de Givry. What he hoped for was to reap glory for his family and strengthen the reputation of the Corps. At the same time, another French fleet that had been sent before the war from Toulon to North America was under the command of the Comte d'Estaing (1729-94), a general who had been appointed lieutenant général des armées navales by the Court immediately after the end of the Seven Years' War. D'Estaing's fast-track promotion was resented by the Grand Corps as an interference directly attributable to favouritism. A haughty and vain demagogue, D'Estaing often behaved horribly. By contrast, d'Orvilliers was highly praised for being a competent and affable officer, who was born into and grew up in the Grand Corps. He clearly met his fellow officers' expectations. He showed himself in the most favourable light. He behaved courteously but he was firmly aware of issues of precedence and hierarchy. Maintaining his rank now was a top priority. As a lieutenant général d'armée navale, he kept his table on board his flagship La Bretagne with splendour and refinement, taking on board a thousand bottles of Margaux and Sauternes.

Unlike Suffren a few years later, d'Orvilliers went out of his way to set up a council of war with his flag officers and captains. He read them the royal instructions stemming from the Secrétaire d'Etat de la Marine and explained to each of them what his expectations were. In the early stages of the war, these instructions were rather vague but, for the first time since the age of Louis XIV, there was an offensive twist to them. The King and the nation expected d'Orvilliers to restore French maritime prestige. There was a general desire to avenge 1759.

D'Orvilliers clearly thought that, under his firm command, the Grand Corps would be in a good position to efficiently fight against the Royal Navy. But, as the former head of the training squadron, he was perfectly aware of the shortcomings of his fleet and, shortly after their departure from Brest, he tried to carry out some manoeuvres. He flew his flag on the Bretagne, a vessel given to the King by the Brittany estates at the end of the previous war. ${ }^{169}$ His flag captain was Parscau du Plessix and the captain of the fleet the Chevalier du Pavillon. ${ }^{170}$ Both had fought at Quiberon Bay. D'Orvilliers himself was at the head of the White squadron, Du Chaffault at the head of the White and Blue. The command of the Blue squadron, however, was entrusted to the Duke of Chartres, which posed a problem. 
Philippe (1747-93), Duke of Chartres and later of Orléans, was the King's cousin. ${ }^{171} \mathrm{He}$ is also known as Philippe Égalité, the prince who voted for Louis XVI's death sentence. At that time, however, the two branches of the Bourbon family were not yet at odds. The young prince of the blood was hoping to inherit his father-in-law's post of grand amiral de France and make his reputation out of a career in the navy. His career had soared in recent years. He had been promoted to the rank of lieutenant général, a status that clearly reached beyond his true naval experience. ${ }^{172}$ In this capacity, he was flanked by the experienced La Motte-Picquet. The presence of a member of the royal family aspiring to glory could be worthwhile for the navy but it could also be a source of embarrassment for the Secrétaire d'Etat de la Marine as well as for d'Orvilliers. The duke didn't challenge the admiral's authority nor did he lack courage. Yet, at the battle at Ushant, on 27 July 1778, when the whole fleet had tacked, his blue squadron ended in the vanguard in the former place of $\mathrm{Du}$ Chaffault and therefore was in position to lead the movements. ${ }^{173}$ D'Orvilliers ordered him to wear and envelop the British rearguard in an attempt to destroy it, like Tourville had done at Beachy Head and as was recommended too by Bigot de Morogues in his treaty about Naval Tactics (1763). But the duke didn't immediately carry out d'Orvilliers's order and lost time before trying to do so. By then it was too late. The exact reason for such a delay still remains unclear. The duke's entourage may have feared for his safety. Had Du Chaffault been in the duke's shoes, the orders would have been executed without demur. Far from inflicting the decisive blow, the aristocrat among the flag officers had blunted the efficiency and cohesion of the fleet. ${ }^{174}$ There was nothing d'Orvilliers could do to prevent it.

While wanting a clear-cut victory, d'Orvilliers nevertheless scored a strategic and moral point. He did not lose the war in one afternoon and even inflicted heavy casualties on the enemy, who was quite surprised, especially when d'Orvilliers placed his flagship, La Bretagne, alongside the Victory. How extensive the modernisation of the French navy had been was now clear to everyone. While in Britain the acrimonious repercussions of the battle led to the infamous Keppel-Palliser affair, d'Orvilliers managed to keep his squadron in the Channel, forcing the Royal Navy to keep many ships at home, unable to strengthen British forces in North American waters. If nothing more was achieved in the Western Approaches, the Battle of Ushant was celebrated in France because of its impact in terms of restored national pride.

The Spanish alliance was badly needed in the following campaign. ${ }^{175} \mathrm{~A}$ joint naval operation needed to be mounted. D'Orvilliers had by now become a leading naval officer in the eyes of the Court. He was held to be the best French flag officer for the job. ${ }^{176} \mathrm{He}$ met all the necessary requirements: the fame he had acquired through his victory, the esteem he enjoyed among the Grand Corps officers and his touch for diplomacy. ${ }^{177}$ Under these conditions, his task was to sail to Spain, to link up with the Spanish navy under Admiral 
Cordoba. The Franco-Spanish squadrons were then to make their way north to meet the Royal Navy. The difficulties d'Orvilliers had to cope with were considerably greater than before. The French ambassador in Madrid had warned him: 'I must warn you that Monsieur de Cordoba is a very old man, now in his mid-seventies. He is highly regarded in the Spanish navy but, as you may imagine, he suffers from the sort of deficiencies a man of his venerable age has to endure.'178 It seems to have escaped the French ambassador's attention that his addressee was no less than 69 years old. D'Orvilliers responded with the sort of sense of humour he was expected to have 'towards that venerable old man all the attentions and care needed by his age and virtue. ${ }^{179}$ With true diplomatic skills and unlimited patience, d'Orvilliers gained his allies' confidence, especially that of Don Miguel de Gastón, whose help was invaluable in resupplying the French ships that were short of water and food. ${ }^{180}$ However, d'Orvilliers was quickly aware that his allies' manoeuvring at sea was quite defective for want of training. A considerable amount of time was lost. There may be a case to be made that in 1779 the Bourbon cause needed a more daring admiral than d'Orvilliers but, to be fair, there was precious little chance of finding a French admiral with finer skills than him to command the combined fleet. In spite of divergent interests and a lack of preparation on both sides, d'Orvilliers went out of his way to explain to his allies what needed to be done, to take joint decisions and treat them well. There was little time left to enforce a true operational cohesion but he managed to lead the combined fleet up to the Western Approaches. Despite many hurdles, d'Orvilliers's leadership style allowed him to score some major points at sea, but having to deal with Versailles Court politics was quite a different story.

\section{III - Powerless dignity}

By nature, or because of his background and education, d'Orvilliers was not the sort of man to stick his neck out politically. While admired and praised by his subordinates, he was short of friends at Court to promote and defend his reputation. Even after Ushant, he remained a discrete and competent servant of the King and never became a general with the sort of skills you need to wage war on two fronts: one against the King's enemies, another against the many intrigues of life at Court.

Problems at Court cropped up shortly after Ushant. First, the duke of Chartres returned to Brest and then to Versailles and Paris where he was celebrated like a hero. After the whole fleet had returned to port, some dissenting accounts of the events circulated, instilling a doubt as to the reality of the duke's alleged bravery. Whilst many Parisian lampoonists lambasted the duke's misconduct, d'Orvilliers sought to smooth a few feathers, and cautiously avoided commenting on the duke's conduct. However, if Chartres had done nothing wrong, it 
could be said that d'Orvilliers was not immune to criticism for not having followed up his tactical advantage. There was also some suspicion among d'Orvilliers's subordinates. For example, La Motte-Picquet wrote the admiral a letter in justification of the duke's conduct. More serious was the covert yet growing enmity of the Orléans family and faction. Chartres never went to sea again. The following year, after the failure of the Channel campaign when d'Orvilliers had to hand in his resignation, the prevailing opinion among the Grand Corps was that he had suffered the consequences of Chartres's wrath. In November 1778, when d'Orvilliers came to Versailles, he was hurt when the King himself bluntly asked him why he had failed to pursue his campaign after Ushant. A loyal servant of the Crown, he responded that he alone was to blame.

But more trouble and disillusion was to crop up the year after; swimming against the tide of political, diplomatic and naval constraints proved impossible. D'Orvilliers had to prepare the Brest fleet for a joint operation with the Spanish navy. In the first round of the secret talks, however, he was kept in the dark. Only the two Bourbon kings, their foreign ministers Vergennes and Floridablanca, and the ambassadors, Montmorin in Madrid, Aranda in Versailles, took part in the discussions. The main details of the projected naval operations were worked out without prior consultation of the naval officers.

Only after the Treaty of Aranjuez (12 April 1779) were d'Orvilliers and du Pavillon summoned to Versailles to hold talks with Vergennes and Sartine. ${ }^{181}$ The two officers requested that the combined fleet be homogenously arranged, with separate French or Spanish squadrons, and an exclusively French vanguard able to launch a swift attack on the enemy.

Diplomatic reasons made this option impracticable. The same applied to their request to find a better meeting place than Sisargas island, off the coast of Galicia. Contenting the Spanish ally was the requirement that came top of the agenda. The two officers succeeded only in postponing the departure from Brest from 1 May to 1 June, the fleet being in no condition to sail before then. Lack of money and poor preparation led to the first of a string of fateful delays. It is a noticeable fact that, despite his naval experience, d'Orvilliers carried little weight. Nor was there anyone in the Secrétaire d'Etat de la Marine's department at Versailles, not even the Chevalier de Fleurieu (albeit himself a naval officer), to oversee naval preparations in tandem with d'Orvilliers. The difference with the British Board of Admiralty is indeed striking. The available navy was clearly insufficient too. The success of the joint naval operation depended on d'Orvilliers but it took a long time before he became privy to the project. What's more, he was shackled to royal instructions, which remained rather vague on key issues and exaggeratedly detailed in other areas. Worse, when he left Brest, his ships had received only two months' worth of water and food supplies. Now, the slightest delay was likely to foil the project of a joint assault on the Isle of Wight.

Waiting for the Spanish for a whole month near Sisargas (23 June-23 July) brought about a second fateful delay. Water and food supplies were running low. The French fleet was beset by an epidemic which greatly blunted its sail- 
ing and fighting abilities. Once the fleet was ready, unfavourable winds barred access to the Channel. Disease spread into the fleet. D'Orvilliers's only son fell sick and died on 2 August. D'Orvilliers was deeply upset and never quite recovered from this loss, but he staunchly persisted in carrying out the orders he had received. As he wrote to Sartine: 'The Lord has taken away everything I own in this world but I have enough strength left to bring the campaign to a close. ${ }^{182}$ Six days later he made his last will, bequeathing to his nephew maths books and instruments, maritime maps, now useless noble titles, his croix de Saint Louis and family portraits. ${ }^{183}$ The death of his son seems to have taken its toll on him.

In the following month (from early August to early September), he persisted in wanting to lead the combined fleet into the Channel. But he had to cope with overwhelming difficulties: the constant deterioration of his crew's health, the lack of cohesion of the combined fleet and, worst of all, unfavourable winds. Nevertheless, in mid-August he anchored near Plymouth, arousing fear in Cornwall. He then received new instructions giving the fleet a new and different target: not the Isle of Wight any more but an attempted landing on the Cornish coast. He voiced his surprise to Sartine: 'Full of respect and deference for my master's and his council's wisdom, I shall carry out the orders I received with the utmost possible zeal, but I feel I ought to provide you and the Crown with the following observations.... These few words offer a nice summary of d'Orvilliers's leadership style when, driven away from the Channel by the winds, he increasingly disagreed with the King and his ministers. All hopes of immediate victory had vanished; so had the hope of a good understanding with ministers who remained far remote from the reality of naval business. Nevertheless, abiding by his duty came as a consolation for d'Orvilliers.

In early September, however, after having failed to catch Admiral Sir Charles Hardy's Channel Squadron, d'Orvilliers decided not to resume the pursuit and returned to Brest to avoid exhausting his crews, greater difficulties and perhaps defeat. ${ }^{184}$ Perfectly aware that he had reached the limits of his power of keeping the sea, he then wrote to Sartine: 'Let me confess that this was mission impossible for my crew. I don't see how anyone on earth could disagree with me.'

D'Orvilliers was compelled to serve as the scapegoat for a poorly prepared campaign, resigning and then going on to live the life of a recluse. Praised by public opinion a year earlier, he was turned into a laughing stock. Lampoonists in Paris ascribed his failure to his deep but now unfashionable religious faith. With no backing to be expected from the Court, he was defenceless. He withdrew with dignity, issuing neither complaints nor indictments. He never saw the King and his ministers again.

His departure from Brest in September 1779 was a unique event testifying to the extraordinary esteem in which he was held by the French navy. Scipion de Castries was later to describe it as a real triumph because of the way d'Orvilliers was escorted to the City gates by French and Spanish naval officers. ${ }^{185}$ Farewells were so moving that he felt unable to respond. More than 200 officers accom- 
panied him to Landerneau and some even to Morlaix. These farewells can be interpreted as a protest movement of the Grand Corps against the Court and ministers. And it was precisely to the officers of the corps de la marine that d'Orvilliers later wrote exhorting them to obey and serve with dedication and faithfulness, as they had done before.

D'Orvilliers's leadership style displays a very professional attitude made up of naval competence, esprit de corps and dedication. He can be compared with his fellow French flag officers of the American war. He was a fine tactician like Guichen or de Grasse but he lacked the wide experience of naval action of Du Chaffault and Guichen. He was firm, but neither intrepid nor particularly aggressive. Unlike de Grasse he had charisma and led his subordinates by being really able to impress them. However, this accomplished officer was unable to express himself very freely or effectively with ministers, even when he lost his grip on the situation in August 1779 and the failure was largely due to circumstances and decisions beyond his control.

Nor could he contest the monarchical order, the precedence of the Grand Corps, and naval tactics he had learnt and taught. But his faithfulness to the Crown left no room for doubt. During the impending tragedy at sea in summer 1779, when naval and strategic failure was deepened by mourning for his son and the loss of any family future, d'Orvilliers reached his true greatness, just before he disappeared into retreat and silence.

Appendix: D'Orvilliers as seen by the Chevalier du Pavillon in a letter to the Secrétaire d'Etat de la Marine Sartine, 15 September 1779 (AN Marine B ${ }^{4} 154$ ).

«Monseigneur, Mon général vient de me dire qu'il est désapprouvé de n'avoir pas poursuivi l'ennemi plus longtemps et de ne pas avoir ordonné la chasse sans égard à l’ordre prescrit entre les vaisseaux de la ligne de bataille; j'avoue, Monseigneur, que ma surprise est extrême; comment pouvait-il se dispenser de courir sur une flotte signalées à plusieurs reprises par des personnes graves? Si elle se fut trouvée anglaise, on l'aurait bien mieux condamné; enfin, Monseigneur, comment mon Général pouvait-il négliger un seul instant de ressortir de la Manche puisqu'il était menacé de vents de sud-ouest, que l'événement a prouvé qu'il les aurait trouvés; qu'il manquait absolument d'eau, de vivres et même de matelots; vous devez sentir aujourd'hui, Monseigneur, puisque vous connaissez l'état et les progrès de l'épidémie qui ravage tous les vaisseaux du Roi, que quelques jours de retard dans la sortie de la Manche aurait fait perdre au Roi ses vaisseaux et le reste de leurs matelots; ce fait n'est que trop prouvé; il l'est également aux yeux de toute l'armée que jamais son Général n’a été aussi grand, aussi supérieur à l'humanité et aux adversités que dans cette malheureuse campagne, laquelle n'a manqué que parce qu'on a mal choisi le point de réunion des vaisseaux des deux puissances; quant à la poursuite que l'on prétend à 
Paris n’avoir pas été assez vive, parce qu’on n’a pas fait chasser sans ordre une armée ennemie de trente-neuf vaisseaux, il est aisé de répondre à cette méchanceté absurde:

$1^{\circ}$ ) les vaisseaux français nétaient pas ni à portée ni en état de combattre seuls puisqu'ils étaient de vrais hôpitaux plutôt que des vaisseaux de guerre,

$2^{\circ}$ ) les ordres du Roi étaient aussi contraires à de pareilles dispositions puisque les espagnols et les français sont entremêlés dans la ligne de bataille d'après mûr examen de la cour et quoi qu'il ait été proposé dès le principe de composer l'avant-garde de l'armée combinée entièrement de vaisseaux français.

Vous m’avez demandé mon sentiment, Monseigneur, sur tous ses objets; je vous les donne sans détour, et avec la même franchise, j’ai l'honneur de vous assurer que jamais le tableau de ce qui arrive à monsieur d'Orvilliers ne s'effacera de ma mémoire; je tâcherai d'en faire mon profit pour être plus sage et moins ambitieux, car je ne pense pas qu'on puisse montrer plus de force d'âme et de zèle pour le service du Roi que ce digne général en a montré depuis la mort de son fils; j'ajouterai à tout ceci d'après vous-même, Monseigneur, que monsieur d'Orvilliers ne peut être remplacé dans ce moment ni pour la guerre ni pour le cabinet; comment donc est-il possible que de simples propos de quelques individus méprisables puissent nuire à un pareil homme. Je suis avec respect, Monseigneur, votre très humble et très obéissant serviteur. Le chevalier du Pavillon. A bord de la Bretagne le 15 septembre $1779 »$.

\section{Translation:}

\section{Monseigneur,}

My general has just told me that he has been censured for not having pursued the enemy longer and not having ordered the pursuit without reforming the line of battle. I confess, Monseigneur, that I am extremely surprised. How could he excuse himself from running towards a fleet that had been reported several times by reliable people? If it was found to be English, he would have been even more censured. Finally, Monseigneur, how could my general neglect for a single moment getting out of the Channel, as it was threatened by south-west winds. Events have proven that he was right. He had an absolute lack of water, food and even seamen. You must feel today, Monseigneur, since you know the state and the progress of the epidemic that devastates all the King's ships, that a few days of delay in the Channel would have lost the King his ships and the rest of their sailors. This fact is only too obvious. It is also clear to the entire army that never was its general so great 
and so superior in his humanity and his adversities than in this unfortunate campaign, which only failed because of the poorly chosen rendezvous for the vessels of the two powers. As to the pursuit, which, it is alleged in Paris, was not carried out with the proper intensity, he could not chase an enemy fleet of 39 vessels in a disordered state. It is easy to respond to this wicked absurdity:

$1^{\circ}$ ) The French vessels were not in a state to fight alone. They were really hospitals rather than ships of war,

$2^{\circ}$ ) The King's orders were also contrary to such an action because the Spanish and French ships were so intermixed in the line of battle. After mature consideration by the Court, it had been established as a principle that the van of the fleet should consist entirely of French vessels.

You asked me my feelings, Monsignor, on all these things. I have given you it without evasion and with frankness. I have the honour to tell you that the vision of what happened to Mon. d'Orvilliers will never be erased from my memory. I will make it my task to become wiser and less ambitious, because I do not think that we can show more strength of soul and zeal for the service of the King than this worthy General has shown since the death of his son. For you, I would add to all this that Mon. d'Orvilliers cannot be replaced at this time, not in the war nor in the cabinet. So how is it possible that a few despicable individuals could be an obstacle to such a man?

I am with respect, Monseigneur, your very humble and very obedient servant.

Le chevalier du Pavillon

On board La Bretagne

15 September 1779 